\title{
Long-Run and Short-Run Causality between Tourism sector and Economic growth: Evidence of VECM Analysis from COMESA countries
}

\author{
Soanandrasana Dalhia Theodorice, \\ PhD Student Department of Economics and Trade, Hunan University \\ Changsha 410000, Hunan Province, China \\ dalhiatheodorice@,hotmail.com \\ Dr. Willy Tozoke Laou Man Cheong \\ Economist, Applied Economics, Changsha 410000, Hunan Province, China \\ willylaouman@yahoo.com
}

\begin{abstract}
The aim of this paper is to analyze the causal relationship between Tourism sector and GDP growth in eight (8) COMESA countries during the period 2003 to 2017. By performing a vector error-correction model (VECM), our results reveal that no long-run and no short-run causality between the Tourism sector and Economic growth. which is not normal that the tourism sector has no impact on economic growth. this should remind the government, the decision makers to look at what is the problem in tourism sector. This sector should play an important role in boosting a nation's economy.
\end{abstract}

Keywords: Vector error correction, Wald Test, COMESA countries, Tourism sector, Economic growth

DOI: $10.7176 / \mathrm{JESD} / 11-8-13$

Publication date: April $30^{\text {th }} 2020$

\section{INTRODUCTION}

Tourism is an important economic sector for COMESA countries and the number of tourist's arrivals rises continually in this region. The long-run and short-run sustainability of tourism depends on the ability of leaders and tourism professionals to maximize its benefits and minimize its costs and Creating a local tourism industry is not an easy task, but making tourism really "fit" the community requires work. Building up a successful and sustainable tourism industry is like creating any successful and sustainable economic activity.

The tourism industry in the Common Market for Eastern and Southern Africa (COMESA) has grown rapidly in recent years, it prioritizes a timely intervention that will support countries in their efforts to develop tourism as an instrument of poverty reduction, of attracting foreign direct investment and foreign exchange earnings, as a tool to diversify economies, while protecting the environment.

According to COMESA market, the block has over 490 million people, and the GDP of $\$ 657.4$ billion, with the area of 12 million square kilometers, a tourism potential with countless attractions that could increase the region's tourism receipts.Experts say tourism operators' benefits from joint marketing include sharing information, networking opportunities access to bigger and diverse markets regionally and internationally.

The objectives of this study are to investigate the long-run relationship between Tourism sector and Economic growth. And to identify the short-run relationship between Tourism sector and Economic growth. This paper investigates the short-run and long-run causal relationships between Tourism sector and economic growth for the case of eight (8) COMESA countries members: Burundi- Comoros- DR. Congo- Kenya- Mauritius- RwandaUganda- Zambia; due to lack of data, we were unable to use all COMESA countries member; using the panel data and VECM. The testing procedure involves the following steps. At the first step whether each variable contains a unit root will be examined. If the variables contain a unit root, the second step is to test whether there is a longrun cointegration relationship between the variables. If a long-run relationship between the variables is found, the final step is to estimate error correction model in order to infer the Granger causal relationship between the variables. Finally using an appropriate method, the long-run and short-run elasticities of economic growth with respect to electricity consumption will be estimated. 
This study can help readers, decision-makers, politicians or governments to take measure upgrading the link of tourism sector to others economic activities through strong inter-sectoral relationship that are likely to create jobs, open up opportunities and promote economic diversification.

\section{LITERATURE REVIEW}

Ohlan, Ramphul (2017) investigates relationship between tourism and economic growth in India by considering the relative importance of financial development over the period of 1960-2014. The results of newly-developed Bayer and Hanck combined test indicate that tourism, economic growth and financial development are cointegrated. It is shown that the inbound tourism spurs economic growth in India both in long-run and short-run. In addition, the analysis indicates the presence of a long-run one-way Granger-causation running from tourism to economic growth. It is suggested that policies for attracting more international tourists should be promoted.

Webster, Craig, Ivanov, Stanislav (2014) investigates the impact of a destination's competitiveness upon tourism's contribution to economic growth using a cross-section with 131 countries. Destination competitiveness is measured with the World Economic Forum's Travel and Tourism Competitiveness Index, while tourism's contribution to economic growth is measured with the growth decomposition methodology. Results reveal that destination competitiveness has no statistically significant impact on tourism's contribution to economic growth. Tourism policy implications and directions for future research are also discussed.

Christie, Iain, Fernandes, Eneida, Messerli, Hannah, Twining-Ward, Louise (2014) discuss about the quality of Africa's resource endowment for tourism is exceptional, but most countries have only barely developed their tourism potential. The continent receives about $4 \%$ of all international travelers and tourism receipts, but tourism is "significant" ( $>2 \%$ GDP and $>5 \%$ exports) in about half of SSA countries. Countries in Africa are now focusing on tourism as a source of growth and diversification, but with only limited policy guidance from most donors, despite the sector's potential. At present, the World Bank Group (WBG) provides limited support for tourism and has no overall sector strategy, though the CDF, PRSP and CAS are helping to define such strategies in a few countries. This paper gives a broad overview of issues in tourism in Africa and suggests guidelines to assist countries to develop a more coherent framework for tourism. Given its cross-sectoral nature, tourism can only grow sustainably if it is integrated into the country's overall economic, social and physical planning policies. Where national attractions are shared with neighboring countries, joint or regional promotion and marketing can be effective. Partial measures are unlikely to address vested interests, underlying economic relationships and generic social or physical constraints effectively. Government's role is to create the policy framework that will encourage for-profit private investment, and that, in combination with regulatory frameworks, will ensure good economic returns and linkages with other sectors. To be sustainable, tourism requires an open dialogue between the government, the private sector, civil society and local communities to ensure consensual decisions and the generation of economic benefits for a broad spectrum of the population. National policies must conserve the country's cultural and environmental heritage to preserve the resource base on which tourism is based.

Du, Ding, Lew, Alan A. Ng, Pin T. (2014) investigating if tourism development is an additional determinant of income in the presence of the standard income determinants (such as capital accumulation), or if the effects of tourism development on economic growth work through the standard income determinants, instead. Empirically, they develop a tourism-growth model that is an extension of Solow (1956) and estimate our model with a crosssection of 109 countries. Our findings indicate that investments in tourism in and of itself appear to be insufficient for economic growth. Instead, tourism's contribution to the long-term growth of an economy comes through its role as an integral part of a broader development strategy that is more generally focused on standard income determinants.

Holzner, Mario (2011) analyses empirically the danger of a Dutch Disease Effect in tourism dependent countries in the long run. Data on 134 countries of the world over the period 1970-2007 is used. In a first step the long-run relationship between tourism and economic growth is analyzed in a cross-country setting. The results are then checked in a panel data framework on GDP per capita levels that allows to control for reverse causality, nonlinearity and interactive effects. It is found that there is no danger of a Beach Disease Effect. On the contrary, tourism dependent countries do not face real exchange rate distortion and deindustrialization but higher than average economic growth rates. Investment in physical capital, such as for instance transport infrastructure, is complementary to investment in tourism. 
Schubert, Stefan Franz, Brida, Juan Gabriel, Risso, Wiston Adrián (2011) studies the impacts on economic growth of a small tourism-driven economy caused by an increase in the growth rate of international tourism demand. We present a formal model and empirical evidence. The ingredients of the dynamic model are a large population of intertemporally optimizing agents and an AK technology representing tourism production. The model shows that an increase in the growth of tourism demand leads to transitional dynamics with gradually increasing economic growth and increasing terms of trade. In our empirical application, an econometric methodology is applied to annual data of Antigua and Barbuda from 1970 to 2008. We perform a cointegration analysis to look for the existence of a long-run relationship among variables of economic growth, international tourism earnings and the real exchange rate. The exercise confirms the theoretical findings.

Richardson, Robert B (2010) investigate the contribution of tourism to economic growth in Thua Thien Hue province in the period of 1997-2011. They used the growth of real gross domestic product (GDP) as a measure of economic growth and then disaggregated it into economic growth generated by tourism and generated by other industries. Firstly, the paper presents a methodology for measuring the contribution of tourism to the Thua Thien Hue economy; secondly, they examined the impact of tourism earning on economic growth (GDP) in Thua Thien Hue province. They used unit root test, cointegration theory, Error Correction Model (ECM), and Granger causality test in order to identify the relationship between tourism and GDP both in the long-run and short-run. Findings conclude that tourism is one of the important reasons for economic growth in Thua Thien Hue province, Vietnam. The results of this study suggest that the government should focus on economic policies to promote tourism as a potential source of economic growth in that province in Vietnam.

Chen, Ching Fu, Chiou-Wei, Song Zan (2009) examines the causal relationship between tourism expansion and economic growth in two Asian countries: Taiwan and South Korea. An EGARCH-M model with uncertainty factors is employed to examine the direction of causality between tourism expansion and economic growth, as well as the impulse impacts of uncertainty on both variables. The results indicate that the tourism-led economic growth hypothesis is supported for Taiwan while a reciprocal causal relationship is found for South Korea. The significant impacts of uncertainty on growth are also identified.

Balaguer, Jacint, Cantavella-Jordá, Manuel (2002) examines the role of tourism in the Spanish long-run economic development. The tourism-led growth hypothesis is confirmed through cointegration and causality testing. The results indicate that, at least, during the last three decades, economic growth in Spain has been sensible to persistent expansion of international tourism. The increase of this activity has produced multiplier effects over time. External competitivity has also been proved in the model to be a fundamental variable for Spanish economic growth. From the empirical analysis it can be inferred the positive effects on income that government policy, in the adequacy of supply as well as in the promotion of tourist activity, may bring about.

\section{Conceptual Background}

The Common Market for Eastern and Southern Africa (COMESA) was formed in December 1994. It was created to serve as an organization of free independent sovereign States that have agreed to cooperate in developing their natural and human resources for the good of all their people. COMESA is the largest regional economic organization in Africa, with 19 member states and a population of about 390 million which the majority are from rural area.

(COMESA countries include: Burundi - Comoros - D.R. Congo - Djibouti - Egypt - Eritrea - Ethiopia - Kenya - Libya - Madagascar - Malawi - Mauritius - Rwanda - Seychelles - Sudan - Swaziland - Uganda - Zambia Zimbabwe.)

Tourism is an ancient activity, which in the twentieth century took on a global dimension. It is now a fundamental economic sector in many developed and developing countries, making it a key factor in their development. Nowadays tourism is the first service industry in the world. Because of its diversified nature, tourism affects practically all areas of economic activity, it exerts a strong influence on other sectors such as agriculture, construction, crafts, commerce, FDI and especially services transport.

Tourism and agriculture are the things that drive COMESA's economic growth and as we know: tourism continues to be a primary development strategy in the region due to the fact that it is seen as an export-oriented growth and poverty reduction strategy by many countries within COMESA, making it a good tool for regional integration. 14 of the 19 countries had identified tourism as a priority sector, it is a clear sign that tourism has been recognized as a key tool for social, economic and environmental development in many countries within COMESA. 
Over 60 percent of the population depend on the sector for their livelihoods and employment. The sector's contribution to employment ranges from a low of 5 percent of the economically active in Libya to a high of over 90 percent in Rwanda. "The relationship between agriculture and tourism (agro-tourism) has long been conflictual. Agro-tourism is a tourism activity that takes place on the farm and is complementary to agricultural activity. It connects agricultural producers with tourists or day-trippers, allowing them to discover the agricultural sector, agriculture and its production, through the reception and information that their host reserves.

Agriculture is a priority sector as it accounts for more than $32 \%$ of COMESA's gross domestic product and $65 \%$ of foreign exchange earnings, provides a livelihood to about $80 \%$ of the region's labor force and contributes more than $50 \%$ of raw materials to the industrial sector. However, the region has been experiencing a decline in the productiveness and competitiveness of the agricultural sector, resulting in national-level food insecurity.

Also, foreign direct investment has the potential to boost the economy of a country. The impact of FDI on growth generates equally a positive effect on the poverty reduction in the host country, namely by the higher wages paid to the local work force. FDI is also important in terms of job creation and export dynamization.

Foreign Direct Investment (FDI) in tourism would help COMESA countries to mitigate the effect of adverse development gap between developed and developing countries. FDI played a major role in the tourism take-off, inducing the country's economic growth. Hence, most governments in developing countries often place the highest priority on attracting FDI, by experimenting with a variety of policies. On the other hand, the growth of tourist arrivals induces an increasing demand for goods and services such as food, accommodation and transportation. Thus, governments often prefer to attract further FDI to expand domestic products and infrastructure to cover the increasing tourist demand for goods and services.

Given the importance of tourism in both economic growth and sustainable development, special attention, on the one hand, is paid to the causal dynamics between trade and tourism. Empirical studies with the aim of uncovering the causation linkage between international trade and tourism yielded conflicting results.

A report on sustainable trade in the Common Market for Eastern and Southern Africa (COMESA) region comes at a strategic time. Africa's economy is projected to grow at its best rate since the 1970s, and African policymakers are increasingly confident that they are developing the basis for sustained growth. Following the launch of the Free Trade Area (FTA), intra-COMESA trade has been increasing at an average annual rate of $30 \%$.

In the light of explanations, the trade contented travels are also accepted as an important component of tourism. Despite the all disclosure, in many scientific contented studies carried out until today, the role that the trade play, as an important component of tourism demand function, is generally ignored. At this point, present paper differs from existing literature by investigating causation linkage between international trade and tourism.

Such research is important in COMESA countries where the population is still largely rural, agriculture is a major industry, FDI and trade are very important components of tourism and tourism plays an important role in economic growth. Linking tourism, agriculture, FDI and Trade in order to promote economic growth should be a main focus of the Governments of COMESA countries. The purpose of this research is to explore growth in COMESA by focusing on the linkages between tourism, agriculture, FDI and Trade through a case study of some country members of COMESA.

\section{Objectives of the Study}

The primary objective of the study is to analyze the long-run and short-run causality between Tourism sector (number of tourism arrival (NTA), Expend on tourism sector (ETS), agriculture (AGR), Transport on tourism sector (TPT), Exchange rate (EXR), Openness trade (OPT), Foreign Direct Investment (FDI), Employment (EMP) and Technology Transfer (TTR)) and Economic growth.

\section{More Specifically}

1. To investigate the long-run relationship between Tourism sector and Economic growth. 
2. To identify the short-run relationship between Tourism sector and Economic growth.

\section{Hypotheses Developed for the Study}

$\mathrm{H} 0^{\text {1a: }}$ : There is no long-run causality between Tourism sector and Economic growth.

$\mathrm{H} 0^{1 \mathrm{~b}}$ : There is no short-run causality between Tourism sector and Economic growth.

$\mathrm{H}^{2 \mathrm{a}}$ : There is no long-run causality between Economic growth and Tourism sector.

$\mathrm{H} 0^{2 b}$ : There is no short-run causality between Economic growth and Tourism sector.

\section{RESEARCH METHOD}

\subsection{Source of Data and Period of the Study}

The study used secondary data to examine the relationship between Tourism sector and economic growth, the yearly variables for 14 years period from 2003 to 2017. The study used gross Domestic Product (GDP), number of tourism arrival (NTA), Expend on tourism sector (ETS), agriculture (AGR), Transport on tourism sector (TPT), Exchange rate (EXR), Openness trade (OPT), Foreign Direct Investment (FDI), Employment (EMP) and Technology Transfer (TTR). All of our data are collected from world bank data base.

\subsection{Research Methods Used for the Analysis}

The econometric tools, Augmented Dickey Fuller (ADF) test, Johansen cointegration test, Vector error correction models (VECM) and Wald test are used for analysis. First, ADF test is used to examine the stationarity of the two variables. Second, the Johansen cointegration test is used to identify the existence and the number of cointegrating vectors. Finally, with the presence of the cointegrating vectors, the VECM is applied to identify the existence of long-run relationship and Wald test is employed to identify the short-run relationship between those variables used in the study, Tourism sector and economic growth.

\subsubsection{Unit Root Test}

The study is fully based on time series data and hence there arises a need to check for the stationarity in the series. Augmented Dickey Fuller test is used to identify the stationarity in the series of data.

H0: Data are not stationary (Unit root exists)

H1: Data are stationary (Unit root does not exist)

If $\mathrm{ADF}$ statistics exceed critical value, the $\mathrm{H} 0$ can be rejected. Hence the $\mathrm{H} 1$ is accepted which means the data are stationary.

\subsubsection{Johansen Cointegration Test}

When the variables are integrated with same order, the Johansen test of cointegration can be applied. The Johansen (1988) approach determines the number of cointegrated vectors for any given number of non-stationary variables of same order. Johansen uses two statistics for testing the cointegration $\lambda_{\text {trace }}$ and $\lambda_{\max }$ statistics, which are as follows:

$$
\begin{aligned}
& \lambda_{\text {trace }(r)}=-T \sum_{i=r+1} \log (1-\lambda) \\
& \lambda_{\text {trace }(r, r+1)}=T \log \left(1-\lambda_{r+1}\right)
\end{aligned}
$$

Where,

$\mathrm{r}=$ number of separate series 
$\mathrm{T}=$ number of usable observations

$\lambda=$ estimated eigen values

H0: There is no cointegration between Tourism sector and Economic growth $(\mathrm{r}=0)$

H1: There is cointegration between Tourism sector and Economic growth $(r>0)$

The $\mathrm{H} 0$ reveals that the number of distinct cointegrating vector is less than or equal to $r$ against a general alternative that it is $>r$. If the test statistics computed is greater than the table value, reject the $\mathrm{H} 0$ that there are $r$ cointegrating vectors. The presence of a cointegrating relation forms the basis of the vector error specification.

\subsubsection{Vector Error Correction Model}

Vector error correction (VEC) model is a restricted VAR (vector autoregression) designed for use with nonstationary series that are known to be cointegrated. The VEC has cointegration relations built into the specification so that it restricts the long-run behavior of the endogenous variables to converge their cointegrating relationships while allowing for short-run adjustment dynamics (Engle and Granger, 1987). The cointegration term is known as the error correction term since the deviation from long-run equilibrium is corrected gradually through a series of partial short-run adjustments.

If the variables are cointegrated of the same order, then valid error correction model exists between the two variables. The determination of cointegration relationship (cointegrated vector) that shows the presence of longterm relationship between variables, causality relationships must be analyzed with error correction model. The corresponding VEC model is:

$$
\begin{gathered}
\Delta y_{1, t}=\alpha_{1}\left(y_{2, t-1}-\beta y_{1, t-1}\right)+\varepsilon_{1, t} \\
\Delta y_{2, t}=\alpha_{2}\left(y_{2, t-1}-\beta y_{1, t-1}\right)+\varepsilon_{2, t}
\end{gathered}
$$

In this (simple) model, the only right-hand side variable is the error correction term. In long-run equilibrium, this term is equal to zero. However, if $\mathrm{y} 1$ and $\mathrm{y} 2$ deviate from the long-run equilibrium, the error correction term will not be equal to zero and each variable adjusts to partially restore the equilibrium relation. The coefficient measures the speed of adjustment of the ith endogenous variable towards the equilibrium.

\subsubsection{Wald Test}

The short-run causality is also tested using Wald test. The Wald test computes a test statistic based on the unrestricted regression. The Wald statistic measures how close the unrestricted estimates come to satisfy the restrictions under the null hypothesis. If the restrictions are in fact true, then the unrestricted estimates should come close to satisfy the restrictions.

\section{RESULTS AND DISCUSSION}

\subsection{PANEL UNIT ROOT TEST}

The null hypothesis: Series has a unit root Alternative: Series has not a unit root 
Table 1: Panel Unit root results

\begin{tabular}{ccccc}
\hline Variables & Stat & Level & \multicolumn{2}{c}{ First different } \\
& P-Value & Stat & P-Value \\
\hline Innta & 5.25396 & 1.0000 & -8.43346 & 0.0000 \\
Inets & 3.90359 & 1.0000 & -7.90693 & 0.0000 \\
Inagr & -1.92100 & 0.0274 & -8.42450 & 0.0000 \\
Intpt & -0.88864 & 0.1871 & -7.73839 & 0.0000 \\
Inexr & 4.24045 & 1.0000 & -6.52891 & 0.0000 \\
fdi & -1.52279 & 0.0639 & -13.0394 & 0.0000 \\
Inopt & 1.28111 & 0.8999 & -9.64275 & 0.0000 \\
Inemp & 4.53646 & 1.0000 & -8.15658 & 0.0000 \\
Inttr & -0.65283 & 0.2569 & -7.96632 & 0.0000 \\
\hline
\end{tabular}

Source: Author

Here, we are testing the link between lngdp and lnnta, lnets, lnexr, fdi, lnopt, lnemp, lnttr. Our result show that at level all P-value is more than 5\% level of significant meaning that we cannot reject the null hypothesis. Meaning that lnnta, lnets, lnexr, fdi, lnopt, lnemp and lnttr have unit root. At first different, our result show that all the Pvalue are very small 0.0000 less than $5 \%$ level of significant. So, we can reject the null hypothesis that means lnnta, lnets, lnexr, fdi, lnopt, lnemp and lnttr don't have unit root. Conclusion, all our variables lnnta, lnets, lnexr, fdi, lnopt, lnemp and lnttr are I(1), means that our variables are non-stationary at Level but when we convert on first different, they are becoming stationary. Then, lnnta, lnets, lnagr, lntpt, lnexr, fdi, lnopt, lnemp and lnttr are integrated of same order. We can run the cointegration test.

\subsection{FISHER JOHANSEN TEST OF COINTEGRATION}

\section{Table2: Series LNGDP LNNTA}

\begin{tabular}{ccccc}
\hline \hline $\begin{array}{c}\text { Hypothesized } \\
\text { No. of CE(s) }\end{array}$ & $\begin{array}{c}\text { Fisher Stat.* } \\
\text { (from trace test) }\end{array}$ & Prob. & $\begin{array}{c}\text { Fisher Stat.* } \\
\text { (from max-eigen test) }\end{array}$ & Prob. \\
\hline \hline None & 32.73 & 0.0080 & 24.29 & 0.0834 \\
At most 1 & 20.47 & 0.1996 & 20.47 & 0.1996 \\
\hline \hline
\end{tabular}

Source: Author

The result shows that we have two tests come out, from trace test and from max-eigen test. And at None, from trace test P-Value is 0.0080 less than 5\% level of significant, so we can reject the null Hypothesis and from maxeigen test P-value is 0.0834 is more than 5\% level of significant, so we cannot reject the null hypothesis. And at most 1, P-value from trace test and from max-eigen test are more than 5\% level of significant. Meaning that we cannot reject the null hypothesis. So lngdp and lnnta are not cointegrated.

Table 3: Series LNGDP LNETS

\begin{tabular}{ccccc}
\hline $\begin{array}{c}\text { Hypothesized } \\
\text { No. of CE(s) }\end{array}$ & $\begin{array}{c}\text { Fisher Stat.* } \\
\text { (from trace test) }\end{array}$ & Prob. & $\begin{array}{c}\text { Fisher Stat.* } \\
\text { (from max-eigen test) }\end{array}$ & Prob. \\
\hline \hline None & 44.56 & 0.0002 & 44.85 & 0.0001 \\
At most 1 & 13.45 & 0.6398 & 13.45 & 0.6398 \\
\hline \hline
\end{tabular}

Source: Author

Here, at None, P-value from trace test and from max-eigen test are small, means that less than $5 \%$ level of significant, so we can reject the null hypothesis. And at most 1, P-value from trace test and from max-eigen test are more than $5 \%$ level of significant. Meaning that we cannot reject the null hypothesis. So lngdp and lnets are cointegrated. 
Table 4: Series LNGDP LNAGR

\begin{tabular}{|c|c|c|c|c|}
\hline $\begin{array}{l}\text { Hypothesized } \\
\text { No. of CE(s) }\end{array}$ & $\begin{array}{c}\text { Fisher Stat.* } \\
\text { (from trace test) }\end{array}$ & Prob. & $\begin{array}{c}\text { Fisher Stat.* } \\
\text { (from max-eigen test) }\end{array}$ & Prob. \\
\hline None & 34.02 & 0.0054 & 21.72 & 0.1524 \\
\hline At most 1 & 43.78 & 0.0002 & 43.78 & 0.0002 \\
\hline
\end{tabular}

Source: Author

Our result here, at None, from trace test P-Value is 0.0054 less than $5 \%$ of significant and from max-eigen test is 0.1524 are more than $5 \%$ level of significant, so we can reject the null Hypothesis. And at most 1 , P-value from trace test is 0.0002 and from max-eigen test are more is 0.0002 are less than $5 \%$ level of significant. Meaning that we can reject the null hypothesis. So lngdp and lnagr are not cointegrated.

Table 5: Series LNGDP LNTPT

\begin{tabular}{ccccc}
\hline \hline $\begin{array}{c}\text { Hypothesized } \\
\text { No. of CE(s) }\end{array}$ & $\begin{array}{c}\text { Fisher Stat.* } \\
\text { (from trace test) }\end{array}$ & Prob. & $\begin{array}{c}\text { Fisher Stat.* } \\
\text { (from max-eigen test) }\end{array}$ & Prob. \\
\hline \hline None & 25.14 & 0.0673 & 17.81 & 0.3352 \\
At most 1 & 29.74 & 0.0194 & 29.74 & 0.0194 \\
\hline \hline
\end{tabular}

Source: Author

At the result, at None, P-value from trace test and from max-eigen test are big, means that more than 5\% level of significant, so we cannot reject the null hypothesis. And at most 1, P-value from trace test and from max-eigen test are smaller than 5\% level of significant. Meaning that we can reject the null hypothesis. So lngdp and lntpt are cointegrated.

Table 6: Series LNGDP LNEXR

\begin{tabular}{ccccc}
\hline $\begin{array}{c}\text { Hypothesized } \\
\text { No. of CE(s) }\end{array}$ & $\begin{array}{c}\text { Fisher Stat.* } \\
\text { (from trace test) }\end{array}$ & Prob. & $\begin{array}{c}\text { Fisher Stat.* } \\
\text { (from max-eigen test) }\end{array}$ & Prob. \\
\hline \hline None & 42.93 & 0.0003 & 28.29 & 0.0292 \\
At most 1 & 26.38 & 0.0489 & 26.38 & 0.0489 \\
\hline \hline
\end{tabular}

Source: Author

Our result here, at None, from trace test P-Value is 0.0003 and from max-eigen test is 0.0292 are less than $5 \%$ level of significant, so we can reject the null Hypothesis. And at most 1, P-value from trace test is 0.0489 and from max-eigen test are more is 0.0489 are less than 5\% level of significant. Meaning that we can reject the null hypothesis. So lngdp and lnexr are not cointegrated.

Table 7: Series LNGDP FDI

\begin{tabular}{ccccc}
\hline $\begin{array}{c}\text { Hypothesized } \\
\text { No. of CE(s) }\end{array}$ & $\begin{array}{c}\text { Fisher Stat.* } \\
\text { (from trace test) }\end{array}$ & Prob. & Fisher Stat.* \\
(from max-eigen test) & Prob. \\
\hline \hline None & 59.85 & 0.0000 & 51.37 & 0.0000 \\
At most 1 & 23.98 & 0.0899 & 23.98 & 0.0899 \\
\hline \hline
\end{tabular}

Source: Author 
Here, at None, P-value from trace test and from max-eigen test are small, means that less than $5 \%$ level of significant, so we can reject the null hypothesis. And at most 1, P-value from trace test and from max-eigen test are more than $5 \%$ level of significant. Meaning that we cannot reject the null hypothesis. So lngdp and fdi are cointegrated.

Table 8: Series LNGDP LNOPT

\begin{tabular}{ccccc}
\hline \hline $\begin{array}{c}\text { Hypothesized } \\
\text { No. of CE(s) }\end{array}$ & $\begin{array}{c}\text { Fisher Stat.* } \\
\text { (from trace test) }\end{array}$ & Prob. & $\begin{array}{c}\text { Fisher Stat.* } \\
\text { (from max-eigen test) }\end{array}$ & Prob. \\
\hline \hline None & 49.87 & 0.0000 & 45.61 & 0.0001 \\
At most 1 & 20.00 & 0.2202 & 20.00 & 0.2202 \\
\hline \hline
\end{tabular}

Source: Author

Similarly, at None, P-value from trace test and from max-eigen test are small, means that less than $5 \%$ level of significant, so we can reject the null hypothesis. And at most 1, P-value from trace test and from max-eigen test are more than $5 \%$ level of significant. Meaning that we cannot reject the null hypothesis. So lngdp and lnopt are cointegrated.

Table 9: Series LNGDP LNEMP

\begin{tabular}{ccccc}
\hline \hline $\begin{array}{c}\text { Hypothesized } \\
\text { No. of CE(s) }\end{array}$ & $\begin{array}{c}\text { Fisher Stat.* } \\
\text { (from trace test) }\end{array}$ & Prob. & $\begin{array}{c}\text { Fisher Stat.* } \\
\text { (from max-eigen test) }\end{array}$ & Prob. \\
\hline \hline None & 45.14 & 0.0001 & 37.91 & 0.0016 \\
At most 1 & 20.75 & 0.1884 & 20.75 & 0.1884 \\
\hline \hline
\end{tabular}

Source: Author

Same, at None, P-value from trace test and from max-eigen test are small, means that less than $5 \%$ level of significant, so we can reject the null hypothesis. And at most 1, P-value from trace test and from max-eigen test are more than $5 \%$ level of significant. Meaning that we cannot reject the null hypothesis. So lngdp and lnemp are cointegrated.

Table 10: Series LNGDP LNTTR

\begin{tabular}{ccccc}
\hline \hline $\begin{array}{c}\text { Hypothesized } \\
\text { No. of CE(s) }\end{array}$ & $\begin{array}{c}\text { Fisher Stat.* } \\
\text { (from trace test) }\end{array}$ & Prob. & $\begin{array}{c}\text { Fisher Stat.* } \\
\text { (from max-eigen test) }\end{array}$ & Prob. \\
\hline \hline None & 65.61 & 0.0000 & 64.94 & 0.0000 \\
At most 1 & 19.56 & 0.2406 & 19.56 & 0.2406 \\
\hline \hline
\end{tabular}

Source: Author

Here, at None, P-value from trace test and from max-eigen test are small, means that less than $5 \%$ level of significant, so we can reject the null hypothesis. And at most 1 , P-value from trace test and from max-eigen test are more than 5\% level of significant. Meaning that we cannot reject the null hypothesis. So lngdp and fdi are cointegrated.

Conclusion, we can run the panel VECM model test with lngdp and lnets, lntpt, fdi, lnopt, lnemp, lnttr. Because they are cointegrated. 


\subsection{PANEL VECM MODEL}

Table 10: Panel VECM Model results

\begin{tabular}{|c|c|c|c|c|c|c|c|}
\hline Error Correction: & D(LNGDP) & D(LNETS) & D(LNTPT) & D(FDI) & D(LNOPT) & D(LNEMP) & D(LNTTR) \\
\hline CointEq1 & $\begin{array}{c}0.000759 \\
(0.00448) \\
{[0.16931]}\end{array}$ & $\begin{array}{r}-0.044499 \\
(0.07015) \\
{[-0.63437]}\end{array}$ & $\begin{array}{c}0.049787 \\
(0.07693) \\
{[0.64714]}\end{array}$ & $\begin{array}{c}1.156133 \\
(0.26279) \\
{[4.39943]}\end{array}$ & $\begin{array}{c}0.040700 \\
(0.02987) \\
{[1.36277]}\end{array}$ & $\begin{array}{c}0.008605 \\
(0.00542) \\
{[1.58852]}\end{array}$ & $\begin{array}{c}-0.001133 \\
(0.01462) \\
{[-0.07749]}\end{array}$ \\
\hline D(LNGDP(-1)) & $\begin{array}{c}0.405839 \\
(0.12344) \\
{[3.28774]}\end{array}$ & $\begin{array}{r}-0.753227 \\
(1.93237) \\
{[-0.38980]}\end{array}$ & $\begin{array}{r}-0.912726 \\
(2.11931) \\
{[-0.43067]}\end{array}$ & $\begin{array}{c}28.96986 \\
(7.23921) \\
{[4.00180]}\end{array}$ & $\begin{array}{r}-0.482476 \\
(0.82271) \\
{[-0.58645]}\end{array}$ & $\begin{array}{c}0.040777 \\
(0.14923) \\
{[0.27325]}\end{array}$ & $\begin{array}{c}0.427386 \\
(0.40285) \\
{[1.06089]}\end{array}$ \\
\hline $\mathrm{D}(\operatorname{LNGDP}(-2))$ & $\begin{array}{c}0.363246 \\
(0.12556) \\
{[2.89307]}\end{array}$ & $\begin{array}{r}1.063379 \\
(1.96551) \\
{[0.54102]}\end{array}$ & $\begin{array}{c}2.785371 \\
(2.15566) \\
{[1.29212]}\end{array}$ & $\begin{array}{c}3.762270 \\
(7.36336) \\
{[0.51094]}\end{array}$ & $\begin{array}{c}1.085017 \\
(0.83682) \\
{[1.29660]}\end{array}$ & $\begin{array}{c}0.140660 \\
(0.15179) \\
{[0.92668]}\end{array}$ & $\begin{array}{r}-0.255331 \\
(0.40976) \\
{[-0.62312]}\end{array}$ \\
\hline D(LNETS(-1)) & $\begin{array}{c}-0.001687 \\
(0.01122) \\
{[-0.15038]}\end{array}$ & $\begin{array}{r}-0.046433 \\
(0.17563) \\
{[-0.26438]}\end{array}$ & $\begin{array}{r}-0.201742 \\
(0.19262) \\
{[-1.04734]}\end{array}$ & $\begin{array}{r}-1.044367 \\
(0.65797) \\
{[-1.58726]}\end{array}$ & $\begin{array}{c}-0.035061 \\
(0.07478) \\
{[-0.46889]}\end{array}$ & $\begin{array}{c}0.001312 \\
(0.01356) \\
{[0.09671]}\end{array}$ & $\begin{array}{r}-0.036558 \\
(0.03662) \\
{[-0.99844]}\end{array}$ \\
\hline D(LNETS(-2)) & $\begin{array}{c}-0.014095 \\
(0.01122) \\
{[-1.25652]}\end{array}$ & $\begin{array}{r}0.148835 \\
(0.17560) \\
{[0.84757]}\end{array}$ & $\begin{array}{c}0.127692 \\
(0.19259) \\
{[0.66302]}\end{array}$ & $\begin{array}{c}0.223077 \\
(0.65786) \\
{[0.33910]}\end{array}$ & $\begin{array}{c}0.051613 \\
(0.07476) \\
{[0.69036]}\end{array}$ & $\begin{array}{c}0.006034 \\
(0.01356) \\
{[0.44494]}\end{array}$ & $\begin{array}{c}0.016697 \\
(0.03661) \\
{[0.45608]}\end{array}$ \\
\hline D(LNTPT(-1)) & $\begin{array}{c}0.000832 \\
(0.01021) \\
{[0.08153]}\end{array}$ & $\begin{array}{r}0.006084 \\
(0.15982) \\
{[0.03807]}\end{array}$ & $\begin{array}{c}0.175683 \\
(0.17529) \\
{[1.00227]}\end{array}$ & $\begin{array}{c}0.647825 \\
(0.59875) \\
{[1.08197]}\end{array}$ & $\begin{array}{c}0.023361 \\
(0.06805) \\
{[0.34331]}\end{array}$ & $\begin{array}{c}0.007173 \\
(0.01234) \\
{[0.58114]}\end{array}$ & $\begin{array}{c}0.042272 \\
(0.03332) \\
{[1.26869]}\end{array}$ \\
\hline D(LNTPT(-2)) & $\begin{array}{c}0.005387 \\
(0.01043) \\
{[0.51625]}\end{array}$ & $\begin{array}{r}-0.072280 \\
(0.16334) \\
{[-0.44251]}\end{array}$ & $\begin{array}{r}-0.131705 \\
(0.17914) \\
{[-0.73520]}\end{array}$ & $\begin{array}{c}0.165491 \\
(0.61192) \\
{[0.27044]}\end{array}$ & $\begin{array}{r}-0.048817 \\
(0.06954) \\
{[-0.70197]}\end{array}$ & $\begin{array}{c}0.001720 \\
(0.01261) \\
{[0.13632]}\end{array}$ & $\begin{array}{r}-0.026567 \\
(0.03405) \\
{[-0.78018]}\end{array}$ \\
\hline $\mathrm{D}(\mathrm{FDI}(-1))$ & $\begin{array}{r}-0.002594 \\
(0.00186) \\
{[-1.39206]}\end{array}$ & $\begin{array}{r}-0.002289 \\
(0.02917) \\
{[-0.07850]}\end{array}$ & $\begin{array}{c}0.002009 \\
(0.03199) \\
{[0.06281]}\end{array}$ & $\begin{array}{c}-0.345918 \\
(0.10926) \\
{[-3.16598]}\end{array}$ & $\begin{array}{c}0.012322 \\
(0.01242) \\
{[0.99236]}\end{array}$ & $\begin{array}{r}0.002414 \\
(0.00225) \\
{[1.07189]}\end{array}$ & $\begin{array}{c}0.001940 \\
(0.00608) \\
{[0.31915]}\end{array}$ \\
\hline $\mathrm{D}(\mathrm{FDI}(-2))$ & $\begin{array}{c}-0.002898 \\
(0.00181) \\
{[-1.60178]}\end{array}$ & $\begin{array}{r}-0.017187 \\
(0.02832) \\
{[-0.60682]}\end{array}$ & $\begin{array}{c}0.003077 \\
(0.03106) \\
{[0.09904]}\end{array}$ & $\begin{array}{c}-0.182306 \\
(0.10611) \\
{[-1.71813]}\end{array}$ & $\begin{array}{r}-0.014984 \\
(0.01206) \\
{[-1.24258]}\end{array}$ & $\begin{array}{c}-0.001099 \\
(0.00219) \\
{[-0.50257]}\end{array}$ & $\begin{array}{c}-0.007160 \\
(0.00590) \\
{[-1.21264]}\end{array}$ \\
\hline D(LNOPT(-1)) & $\begin{array}{c}0.009855 \\
(0.01979) \\
{[0.49792]}\end{array}$ & $\begin{array}{c}0.297176 \\
(0.30984) \\
{[0.95912]}\end{array}$ & $\begin{array}{c}0.388316 \\
(0.33982) \\
{[1.14272]}\end{array}$ & $\begin{array}{c}1.189909 \\
(1.16076) \\
{[1.02511]}\end{array}$ & $\begin{array}{r}-0.130955 \\
(0.13192) \\
{[-0.99272]}\end{array}$ & $\begin{array}{c}0.006134 \\
(0.02393) \\
{[0.25634]}\end{array}$ & $\begin{array}{c}0.036702 \\
(0.06460) \\
{[0.56818]}\end{array}$ \\
\hline D(LNOPT(-2)) & $\begin{array}{c}0.003461 \\
(0.01906) \\
{[0.18152]}\end{array}$ & $\begin{array}{r}-0.612361 \\
(0.29844) \\
{[-2.05187]}\end{array}$ & $\begin{array}{r}-0.748156 \\
(0.32731) \\
{[-2.28575]}\end{array}$ & $\begin{array}{c}0.458370 \\
(1.11805) \\
{[0.40997]}\end{array}$ & $\begin{array}{r}-0.336560 \\
(0.12706) \\
{[-2.64878]}\end{array}$ & $\begin{array}{r}-0.014554 \\
(0.02305) \\
{[-0.63147]}\end{array}$ & $\begin{array}{c}-0.060370 \\
(0.06222) \\
{[-0.97030]}\end{array}$ \\
\hline D(LNEMP(-1)) & $\begin{array}{c}0.050513 \\
(0.10753) \\
{[0.46976]}\end{array}$ & $\begin{array}{r}1.665675 \\
(1.68328) \\
{[0.98954]}\end{array}$ & $\begin{array}{c}1.308763 \\
(1.84613) \\
{[0.70892]}\end{array}$ & $\begin{array}{c}-13.47119 \\
(6.30606) \\
{[-2.13623]}\end{array}$ & $\begin{array}{c}0.835463 \\
(0.71666) \\
{[1.16577]}\end{array}$ & $\begin{array}{c}-0.048897 \\
(0.12999) \\
{[-0.37615]}\end{array}$ & $\begin{array}{r}-0.160759 \\
(0.35093) \\
{[-0.45810]}\end{array}$ \\
\hline D(LNEMP(-2)) & $\begin{array}{c}0.049988 \\
(0.07259) \\
{[0.68860]}\end{array}$ & $\begin{array}{r}-0.454129 \\
(1.13639) \\
{[-0.39962]}\end{array}$ & $\begin{array}{r}-1.118702 \\
(1.24633) \\
{[-0.89760]}\end{array}$ & $\begin{array}{c}-0.834902 \\
(4.25724) \\
{[-0.19611]}\end{array}$ & $\begin{array}{r}-0.296428 \\
(0.48382) \\
{[-0.61268]}\end{array}$ & $\begin{array}{c}0.053656 \\
(0.08776) \\
{[0.61139]}\end{array}$ & $\begin{array}{r}-0.028635 \\
(0.23691) \\
{[-0.12087]}\end{array}$ \\
\hline D(LNTTR(-1)) & 0.029083 & 0.451994 & 0.294304 & 4.937105 & 0.130609 & -0.068468 & 0.019990 \\
\hline
\end{tabular}




\begin{tabular}{|c|c|c|c|c|c|c|c|}
\hline \multirow[b]{2}{*}{ D(LNTTR(-2)) } & $\begin{array}{r}(0.03849) \\
{[0.75566]}\end{array}$ & $\begin{array}{r}(0.60248) \\
{[0.75022]}\end{array}$ & $\begin{array}{c}(0.66077) \\
{[0.44540]}\end{array}$ & $\begin{array}{r}(2.25707) \\
{[2.18739]}\end{array}$ & $\begin{array}{r}(0.25651) \\
{[0.50918]}\end{array}$ & $\begin{array}{c}(0.04653) \\
{[-1.47154]}\end{array}$ & $\begin{array}{r}(0.12560) \\
{[0.15915]}\end{array}$ \\
\hline & $\begin{array}{r}-0.049142 \\
(0.03486) \\
{[-1.40970]}\end{array}$ & $\begin{array}{c}0.325830 \\
(0.54570) \\
{[0.59708]}\end{array}$ & $\begin{array}{c}0.687645 \\
(0.59850) \\
{[1.14895]}\end{array}$ & $\begin{array}{r}-1.691174 \\
(2.04437) \\
{[-0.82723]}\end{array}$ & $\begin{array}{r}-0.291355 \\
(0.23234) \\
{[-1.25403]}\end{array}$ & $\begin{array}{c}0.024051 \\
(0.04214) \\
{[0.57069]}\end{array}$ & $\begin{array}{r}-0.023545 \\
(0.11377) \\
{[-0.20695]}\end{array}$ \\
\hline $\mathrm{C}$ & $\begin{array}{c}0.004572 \\
(0.00403) \\
{[1.13568]}\end{array}$ & $\begin{array}{c}0.034913 \\
(0.06303) \\
{[0.55394]}\end{array}$ & $\begin{array}{r}0.011556 \\
(0.06912) \\
{[0.16718]}\end{array}$ & $\begin{array}{r}-0.642124 \\
(0.23611) \\
{[-2.71955]}\end{array}$ & $\begin{array}{r}-0.015557 \\
(0.02683) \\
{[-0.57975]}\end{array}$ & $\begin{array}{c}0.003764 \\
(0.00487) \\
{[0.77339]}\end{array}$ & $\begin{array}{r}-0.001734 \\
(0.01314) \\
{[-0.13200]}\end{array}$ \\
\hline R-squared & 0.452753 & 0.134011 & 0.141099 & 0.485277 & 0.283959 & 0.133419 & 0.133574 \\
\hline Adj. R-squared & 0.350144 & -0.028362 & -0.019944 & 0.388766 & 0.149701 & -0.029065 & -0.028880 \\
\hline Sum sq. resids & 0.032469 & 7.956785 & 9.570822 & 111.6712 & 1.442292 & 0.047454 & 0.345825 \\
\hline S.E. equation & 0.020146 & 0.315372 & 0.345883 & 1.181478 & 0.134271 & 0.024355 & 0.065748 \\
\hline F-statistic & 4.412413 & 0.825330 & 0.876155 & 5.028220 & 2.115030 & 0.821118 & 0.822225 \\
\hline Log likelihood & 247.3887 & -16.68259 & -25.54790 & -143.4762 & 65.29139 & 229.1741 & 133.8381 \\
\hline Akaike AIC & -4.820599 & 0.680887 & 0.865581 & 3.322421 & -1.026904 & -4.441127 & -2.454961 \\
\hline Schwarz SC & -4.393208 & 1.108279 & 1.292973 & 3.749812 & -0.599513 & -4.013736 & -2.027570 \\
\hline Mean dependent & 0.025131 & 0.058622 & 0.059880 & 0.041282 & 0.003736 & 0.010092 & -0.001226 \\
\hline S.D. dependent & 0.024991 & 0.310993 & 0.342485 & 1.511199 & 0.145612 & 0.024009 & 0.064819 \\
\hline \multicolumn{2}{|c|}{ Determinant resid covariance (dof adj.) } & $3.03 \mathrm{E}-14$ & & & & & \\
\hline \multicolumn{2}{|c|}{ Determinant resid covariance } & $8.46 \mathrm{E}-15$ & & & & & \\
\hline \multicolumn{2}{|c|}{ Log likelihood } & 601.8566 & & & & & \\
\hline \multicolumn{2}{|c|}{ Akaike information criterion } & -10.05951 & & & & & \\
\hline \multicolumn{2}{|l|}{ Schwarz criterion } & -6.880789 & & & & & \\
\hline \multicolumn{2}{|c|}{ Number of coefficients } & 119 & & & & & \\
\hline
\end{tabular}

Source: Author

Table 10: Estimation Method Least Squares

\begin{tabular}{lrrrr}
\hline \hline & Coefficient & Std. Error & t-Statistic & Prob. \\
\hline \hline $\mathrm{C}(1)$ & 0.000759 & 0.004481 & 0.169311 & 0.8656 \\
$\mathrm{C}(2)$ & 0.405839 & 0.123440 & 3.287736 & 0.0011 \\
$\mathrm{C}(3)$ & 0.363246 & 0.125557 & 2.893068 & 0.0040 \\
$\mathrm{C}(4)$ & -0.001687 & 0.011219 & -0.150381 & 0.8805 \\
$\mathrm{C}(5)$ & -0.014095 & 0.011217 & -1.256516 & 0.2095 \\
$\mathrm{C}(6)$ & 0.000832 & 0.010210 & 0.081528 & 0.9351 \\
$\mathrm{C}(7)$ & 0.005387 & 0.010434 & 0.516249 & 0.6059 \\
$\mathrm{C}(8)$ & -0.002594 & 0.001863 & -1.392056 & 0.1645 \\
$\mathrm{C}(9)$ & -0.002898 & 0.001809 & -1.601778 & 0.1098 \\
$\mathrm{C}(10)$ & 0.009855 & 0.019793 & 0.497919 & 0.6187 \\
$\mathrm{C}(11)$ & 0.003461 & 0.019065 & 0.181516 & 0.8560 \\
$\mathrm{C}(12)$ & 0.050513 & 0.107529 & 0.469762 & 0.6387 \\
$\mathrm{C}(13)$ & 0.049988 & 0.072593 & 0.688604 & 0.4914 \\
$\mathrm{C}(14)$ & 0.029083 & 0.038487 & 0.755656 & 0.4502 \\
$\mathrm{C}(15)$ & -0.049142 & 0.034860 & -1.409700 & 0.1592 \\
$\mathrm{C}(16)$ & 0.004572 & 0.004026 & 1.135682 & 0.2566 \\
$\mathrm{C}(17)$ & -0.044499 & 0.070147 & -0.634368 & 0.5261 \\
$\mathrm{C}(18)$ & -0.753227 & 1.932366 & -0.389795 & 0.6968 \\
$\mathrm{C}(19)$ & 1.063379 & 1.965505 & 0.541021 & 0.5887 \\
$\mathrm{C}(20)$ & -0.046433 & 0.175632 & -0.264376 & 0.7916 \\
$\mathrm{C}(21)$ & 0.148835 & 0.175602 & 0.847570 & 0.3970 \\
$\mathrm{C}(22)$ & 0.006084 & 0.159823 & 0.038070 & 0.9696 \\
$\mathrm{C}(23)$ & -0.072280 & 0.163340 & -0.442509 & 0.6583 \\
& & & & \\
\hline
\end{tabular}




\begin{tabular}{|c|c|c|c|c|}
\hline $\mathrm{C}(24)$ & -0.002289 & 0.029165 & -0.078498 & 0.9375 \\
\hline$C(25)$ & -0.017187 & 0.028323 & -0.606820 & 0.5442 \\
\hline $\mathrm{C}(26)$ & 0.297176 & 0.309842 & 0.959121 & 0.3379 \\
\hline $\mathrm{C}(27)$ & -0.612361 & 0.298441 & -2.051867 & 0.0406 \\
\hline $\mathrm{C}(28)$ & 1.665675 & 1.683280 & 0.989541 & 0.3228 \\
\hline $\mathrm{C}(29)$ & -0.454129 & 1.136388 & -0.399625 & 0.6896 \\
\hline$C(30)$ & 0.451994 & 0.602482 & 0.750220 & 0.4534 \\
\hline $\mathrm{C}(31)$ & 0.325830 & 0.545705 & 0.597080 & 0.5507 \\
\hline$C(32)$ & 0.034913 & 0.063026 & 0.553942 & 0.5798 \\
\hline $\mathrm{C}(33)$ & 0.049787 & 0.076933 & 0.647140 & 0.5178 \\
\hline $\mathrm{C}(34)$ & -0.912726 & 2.119314 & -0.430670 & 0.6669 \\
\hline$C(35)$ & 2.785371 & 2.155659 & 1.292121 & 0.1968 \\
\hline$C(36)$ & -0.201742 & 0.192623 & -1.047338 & 0.2954 \\
\hline $\mathrm{C}(37)$ & 0.127692 & 0.192590 & 0.663024 & 0.5076 \\
\hline $\mathrm{C}(38)$ & 0.175683 & 0.175286 & 1.002267 & 0.3166 \\
\hline $\mathrm{C}(39)$ & -0.131705 & 0.179143 & -0.735197 & 0.4625 \\
\hline $\mathrm{C}(40)$ & 0.002009 & 0.031987 & 0.062806 & 0.9499 \\
\hline $\mathrm{C}(41)$ & 0.003077 & 0.031063 & 0.099042 & 0.9211 \\
\hline$C(42)$ & 0.388316 & 0.339818 & 1.142718 & 0.2536 \\
\hline $\mathrm{C}(43)$ & -0.748156 & 0.327314 & -2.285748 & 0.0226 \\
\hline $\mathrm{C}(44)$ & 1.308763 & 1.846130 & 0.708923 & 0.4787 \\
\hline $\mathrm{C}(45)$ & -1.118702 & 1.246328 & -0.897598 & 0.3698 \\
\hline $\mathrm{C}(46)$ & 0.294304 & 0.660770 & 0.445396 & 0.6562 \\
\hline$C(47)$ & 0.687645 & 0.598499 & 1.148949 & 0.2511 \\
\hline $\mathrm{C}(48)$ & 0.011556 & 0.069124 & 0.167183 & 0.8673 \\
\hline $\mathrm{C}(49)$ & 1.156133 & 0.262791 & 4.399433 & 0.0000 \\
\hline $\mathrm{C}(50)$ & 28.96986 & 7.239211 & 4.001799 & 0.0001 \\
\hline $\mathrm{C}(51)$ & 3.762270 & 7.363358 & 0.510945 & 0.6096 \\
\hline $\mathrm{C}(52)$ & -1.044367 & 0.657968 & -1.587260 & 0.1130 \\
\hline $\mathrm{C}(53)$ & 0.223077 & 0.657855 & 0.339097 & 0.7347 \\
\hline $\mathrm{C}(54)$ & 0.647825 & 0.598745 & 1.081972 & 0.2797 \\
\hline $\mathrm{C}(55)$ & 0.165491 & 0.611921 & 0.270445 & 0.7869 \\
\hline$C(56)$ & -0.345918 & 0.109261 & -3.165984 & 0.0016 \\
\hline$C(57)$ & -0.182306 & 0.106107 & -1.718129 & 0.0863 \\
\hline $\mathrm{C}(58)$ & 1.189909 & 1.160759 & 1.025113 & 0.3058 \\
\hline C(59) & 0.458370 & 1.118047 & 0.409974 & 0.6820 \\
\hline $\mathrm{C}(60)$ & -13.47119 & 6.306062 & -2.136229 & 0.0331 \\
\hline$C(61)$ & -0.834902 & 4.257242 & -0.196113 & 0.8446 \\
\hline $\mathrm{C}(62)$ & 4.937105 & 2.257075 & 2.187391 & 0.0291 \\
\hline$C(63)$ & -1.691174 & 2.044370 & -0.827235 & 0.4085 \\
\hline $\mathrm{C}(64)$ & -0.642124 & 0.236114 & -2.719551 & 0.0067 \\
\hline$C(65)$ & 0.040700 & 0.029865 & 1.362770 & 0.1735 \\
\hline $\mathrm{C}(66)$ & -0.482476 & 0.822711 & -0.586446 & 0.5578 \\
\hline$C(67)$ & 1.085017 & 0.836820 & 1.296596 & 0.1953 \\
\hline$C(68)$ & -0.035061 & 0.074776 & -0.468886 & 0.6393 \\
\hline$C(69)$ & 0.051613 & 0.074763 & 0.690360 & 0.4903 \\
\hline$C(70)$ & 0.023361 & 0.068045 & 0.343309 & 0.7315 \\
\hline $\mathrm{C}(71)$ & -0.048817 & 0.069543 & -0.701966 & 0.4830 \\
\hline$C(72)$ & 0.012322 & 0.012417 & 0.992362 & 0.3214 \\
\hline$C(73)$ & -0.014984 & 0.012059 & -1.242576 & 0.2145 \\
\hline$C(74)$ & -0.130955 & 0.131916 & -0.992716 & 0.3213 \\
\hline$C(75)$ & -0.336560 & 0.127062 & -2.648782 & 0.0083 \\
\hline$C(76)$ & 0.835463 & 0.716662 & 1.165770 & 0.2442 \\
\hline $\mathrm{C}(77)$ & -0.296428 & 0.483821 & -0.612682 & 0.5403 \\
\hline$C(78)$ & 0.130609 & 0.256509 & 0.509179 & 0.6108 \\
\hline$C(79)$ & -0.291355 & 0.232335 & -1.254026 & 0.2104 \\
\hline $\mathrm{C}(80)$ & -0.015557 & 0.026834 & -0.579749 & 0.5623 \\
\hline $\mathrm{C}(81)$ & 0.008605 & 0.005417 & 1.588515 & 0.1127 \\
\hline $\mathrm{C}(82)$ & 0.040777 & 0.149231 & 0.273249 & 0.7848 \\
\hline $\mathrm{C}(83)$ & 0.140660 & 0.151790 & 0.926677 & 0.3545 \\
\hline
\end{tabular}




\begin{tabular}{lrrrr}
$\mathrm{C}(84)$ & 0.001312 & 0.013564 & 0.096709 & 0.9230 \\
$\mathrm{C}(85)$ & 0.006034 & 0.013561 & 0.444935 & 0.6565 \\
$\mathrm{C}(86)$ & 0.007173 & 0.012343 & 0.581144 & 0.5614 \\
$\mathrm{C}(87)$ & 0.001720 & 0.012614 & 0.136318 & 0.8916 \\
$\mathrm{C}(88)$ & 0.002414 & 0.002252 & 1.071893 & 0.2842 \\
$\mathrm{C}(89)$ & -0.001099 & 0.002187 & -0.502575 & 0.6155 \\
$\mathrm{C}(90)$ & 0.006134 & 0.023928 & 0.256339 & 0.7978 \\
$\mathrm{C}(91)$ & -0.014554 & 0.023048 & -0.631470 & 0.5280 \\
$\mathrm{C}(92)$ & -0.048897 & 0.129995 & -0.376146 & 0.7070 \\
$\mathrm{C}(93)$ & 0.053656 & 0.087760 & 0.611391 & 0.5412 \\
$\mathrm{C}(94)$ & -0.068468 & 0.046528 & -1.471540 & 0.1417 \\
$\mathrm{C}(95)$ & 0.024051 & 0.042143 & 0.570690 & 0.5684 \\
$\mathrm{C}(96)$ & 0.003764 & 0.004867 & 0.773388 & 0.4396 \\
$\mathrm{C}(97)$ & -0.001133 & 0.014624 & -0.077488 & 0.9383 \\
$\mathrm{C}(98)$ & 0.427386 & 0.402855 & 1.060893 & 0.2892 \\
$\mathrm{C}(99)$ & -0.255331 & 0.409764 & -0.623119 & 0.5335 \\
$\mathrm{C}(100)$ & -0.036558 & 0.036615 & -0.998440 & 0.3185 \\
$\mathrm{C}(101)$ & 0.016697 & 0.036609 & 0.456079 & 0.6485 \\
$\mathrm{C}(102)$ & 0.042272 & 0.033320 & 1.268687 & 0.2051 \\
$\mathrm{C}(103)$ & -0.026567 & 0.034053 & -0.780175 & 0.4356 \\
$\mathrm{C}(104)$ & 0.001940 & 0.006080 & 0.319146 & 0.7497 \\
$\mathrm{C}(105)$ & -0.007160 & 0.005905 & -1.212640 & 0.2258 \\
$\mathrm{C}(106)$ & 0.036702 & 0.064595 & 0.568180 & 0.5701 \\
$\mathrm{C}(107)$ & -0.060370 & 0.062218 & -0.970302 & 0.3323 \\
$\mathrm{C}(108)$ & -0.160759 & 0.350926 & -0.458098 & 0.6471 \\
$\mathrm{C}(109)$ & -0.028635 & 0.236911 & -0.120867 & 0.9038 \\
$\mathrm{C}(110)$ & 0.019990 & 0.125604 & 0.159149 & 0.8736 \\
$\mathrm{C}(111)$ & -0.023545 & 0.113767 & -0.206955 & 0.8361 \\
$\mathrm{C}(112)$ & -0.001734 & 0.013140 & -0.131997 & 0.8950 \\
\hline \hline
\end{tabular}

$$
\begin{aligned}
& \text { Equation: } \mathrm{D}(\mathrm{LNGDP})=\mathrm{C}(1) *(\mathrm{LNGDP}(-1)+0.350444759031 * \operatorname{LNETS}(-1)- \\
& 0.438752048214 * \mathrm{LNTPT}(-1)-0.415219927418 * \mathrm{FDI}(-1)- \\
& 1.23216666213 * \mathrm{LNOPT}(-1)-1.24731367001 * \mathrm{LNEMP}(-1)+ \\
& 1.7083120285 * \mathrm{LNTTR}(-1)-0.465785810211)+\mathrm{C}(2) * \mathrm{D}(\mathrm{LNGDP}(-1))+ \\
& \mathrm{C}(3) * \mathrm{D}(\mathrm{LNGDP}(-2))+\mathrm{C}(4) * \mathrm{D}(\mathrm{LNETS}(-1))+\mathrm{C}(5) * \mathrm{D}(\mathrm{LNETS}(-2))+\mathrm{C}(6) \\
& * \mathrm{D}(\mathrm{LNTPT}(-1))+\mathrm{C}(7) * \mathrm{D}(\mathrm{LNTPT}(-2))+\mathrm{C}(8) * \mathrm{D}(\mathrm{FDI}(-1))+\mathrm{C}(9) * \mathrm{D}(\mathrm{FDI}( \\
& -2))+\mathrm{C}(10) * \mathrm{D}(\mathrm{LNOPT}(-1))+\mathrm{C}(11) * \mathrm{D}(\mathrm{LNOPT}(-2))+\mathrm{C}(12) * \mathrm{D}(\mathrm{LNEMP}( \\
& -1))+\mathrm{C}(13) * \mathrm{D}(\mathrm{LNEMP}(-2))+\mathrm{C}(14) * \mathrm{D}(\mathrm{LNTTR}(-1))+\mathrm{C}(15) * \mathrm{D}(\mathrm{LNTTR}( \\
& -2))+\mathrm{C}(16) \\
& \text { Observations: } 96
\end{aligned}
$$

Source: Author

The result show that our $\mathrm{C}(1)$ is positive and not significant. Then we can say that is not a long-run causality running from independent lnets, fdi, lnopt, lnemp and lnttr to dependent variable lngdp. Or there would not be speed of adjustment towards long-run equilibrium. 


\subsection{WALD TEST}

Table 11: Wald Test result

\begin{tabular}{lccc}
\hline \hline Test Statistic & Value & df & Probability \\
\hline \hline Chi-square & 1.652424 & 2 & 0.4377 \\
\hline \hline
\end{tabular}

Null Hypothesis: $\mathrm{C}(4)=\mathrm{C}(5)=0$

Null Hypothesis Summary:

\begin{tabular}{lcc}
\hline \hline Normalized Restriction $(=0)$ & Value & Std. Err. \\
\hline \hline $\mathrm{C}(4)$ & -0.001687 & 0.000157 \\
$\mathrm{C}(5)$ & -0.014095 & 0.011217 \\
\hline \hline
\end{tabular}

Source: Author

Here, the probability of Chi-square is 0.4377 very big, mean that more than $5 \%$ level of significant. So, we cannot reject the null hypothesis. There mean that no short-run causality running from independent lnets, fdi, lnopt, lnemp and lnttr to dependent variable lngdp.

Conclusion, there is no long-run and no short-run causality from independent lnets, fdi, lnopt, lnemp and lnttr to dependent variable lngdp.

\section{CONCLUSION AND DISCUSSION}

In global economy, tourism is one of the most noticeable and growing sectors. This sector plays an important role in boosting nation's economy. An increase in tourism flow can bring positive economic outcomes to the nations, especially in gross domestic product (GDP) and employment opportunities. But our result shows that there is no long-run and no short-run causality from independent lnets, fdi, lnopt, lnemp and lnttr to dependent variable lngdp. Meaning that Tourism sector (number of tourism arrival (NTA), Expend on tourism sector (ETS), agriculture (AGR), Transport on tourism sector (TPT), Exchange rate (EXR), Openness trade (OPT), Foreign Direct Investment (FDI), Employment (EMP) and Technology Transfer (TTR) in COMESA countries have no impact on Economic growth in those eight (8) selected countries. This result seems strange compared to what we see in other countries but the cause might be the presence of high level of corruption or mismanagement in Tourism sector in COMESA countries. Government in COMESA Countries should observe and control closely the Tourism Sector in their respective countries to avoid any abuse of tourists and negative impact on their GDP. So, efforts should be directed towards policies that will enhance economic growth, such as the business environment, and openness, in order to have a greater impact on Tourism sector which plays a great role on economic growth.

\section{REFERENCE}

Balaguer, J. and Cantavella-Jordá, M. (2002) Tourism as a long-run economic growth factor: the Spanish case, Applied Economics, 34, 877-884.

Bote Gómez, V. (1993) La necesaria revalorización de la actividad turística española en una economía terciarizada e integrada en la CEE, Revista Estudios Turísticos, 118, 5-26. 
Brohman, J. (1996) New directions in tourism for third world development, Annals of Tourism Research, 23, 4870.

Buisán, A. (1997) Exportaciones de turismo y competitividad, Revista de Economía Aplicada, V (13) 65-81.

Dickey, D. and W. Fuller (1979) Distribution of the Estimators for Autoregressive Time Series with a Unit Root, Journal of the American Statistical Association, 74, 427-431.

Dickey, D. and W. Fuller (1981) Likelihood Ratio Statistics for Autoregressive Time Series with a Unit Root, Econometrica, 49, 1057-1072.

Elliot, G., T.J. Rothenberg, and J.H. Stock (1996) Efficient Tests for an Autoregressive Unit Root, Econometrica, 64, 813-836.

Engle, R.F. and C.W.J. Granger (1987) Cointegration and Error Correction: Representation, Estimation and Testing, Econometrica, 55, 251-276.

Figuerola, M. (1996) Experiencias cuantitativas en el análisis económico del turismo, Estudios Turísticos, 129, 37-58.

Gibson, L.J. (1993) “The potencial for tourism development in nonmetropolitan areas” in D.L. Barkley (ed.) Economic Adaptation: Alternatives for nonmetropolitan areas. Boulder, CO: Westview Press.

Granger, C.W.J. (1969) Investigating causal relations by econometric models and cross spectral methods, Econometrica, 37, 424-438.

Instituto Nacional de Estadística (INE). Statistical Yearbooks 1960-2002. Johansen, S. (1988) Statistical analysis of cointegrating vectors, Journal of Economic Dynamics and Control, 12, 231-54.

Johansen, S. and Juselius, K. (199 Johansen, S. and Juselius, K. (1990), Maximum likelihood estimation and inference on cointegration -with applications to the demand for money, Oxford Bulletin of Economics and Statistics, 52, 169-210.

Kwiatkowski, D., P.C.B. Phillips, P. Schmidt and Y. Shin (1992) Testing the Null Hypothesis of Stationarity Against the Alternative of a Unit Root, Journal of Econometrics, 54, 159-178.

McKinnon, R. (1964) Foreign Exchange constrain in economic development and efficient aid allocation, Economic Journal, 74, 388-409.

Morley, C.L. (1992) A microeconomic theory of international tourism demand, Annals of Tourism Research, 19, 250-267.

Ng, S., and P. Perron (1995) Unit Root Tests in ARMA Models with Data-Dependent Methods for the Selection of the Truncation Lag, Journal of the American Statistical Association, 90, 268-281.

Ng, S., and P. Perron (2001) Lag Length Selection and the Construction of Unit Root Tests with Good Size and Power, Econometrica, 69, 1519-1554.

Padilla, R. (1988) La demanda de servicios turísticos en España, Investigaciones Económicas, 12, 461-472.

Pellejero, C. (2004) Iniciativas y participación del sector público español en el desarrollo del turismo, Papeles de Economía Española, 102, 49-66.

Perron, P. and S. Ng. (1996) Useful Modifications to Some Unit Root Tests with Dependent Errors and their Local Asymptotic Properties, Review of Economic Studies, 63, 435-463. 
Phillips, P.C.B. (1987) Time Series Regression with a Unit Root, Econometrica, 55, 227-301.

Phillips, P.C.B. and P. Perron (1988) Testing for Unit Roots in Time Series Regression, Biometrika, 75, 335-346.

Sinclair, M.T. (1998) Tourism and Economic Development: A Survey, The Journal of Development Studies, 34 (5), 1-51.

Sinclair, M.T. and Bote Gómez, V., (1996) "Tourism, the Spanish Economy and the Balance of Payments", in M. Barke, M. Newton and J. Towner (eds.), Tourism in Spain: Critical Perspectives, Wallingford: C.A.B. International.

Thornton, J. (1997) Exports and economic growth: evidence from 19th century Europe, Economic Letters, 55, 235-50.

Balaguer, J. a.-J., 2002. Tourism as a long-run economic growth, Applied Economics, p. 877-884.

Byrne, D., 2001. Complexity Theory and the Social Sciences, Editor. Taylor \& Francis, New York Duffield, B. S., 1982. Tourism: The Measurement of Economic and Social Impact, Tourism Management, p.248-255.

Hojeghan, S., Esfangareh, A., 2011. Digital Economy and Tourism Impacts, Influences and Challenges, Procedia - Social and Behavioral Sciences, p. 308-316.

Jackson, J. M., 2005. Innovations in Measuring Economic Impacts of Regional Festivals: A Do-It-Yourself Kit, Journal of Travel Research, p. 360-367.

Jenkins, C., \& Henr, B., 1982. Government Involvement in Tourism in Developing Countries, Annals of Tourism Research, p. 499-521.

Lewin, R., 1999. Complexity: Life at the Edge of Chaos, Editor. University of Chicago Press, Chicago. National Tourism Development Master Plan - Executive Summary, World Trade Organization, 2009.

Pao, J. W., 2005. A Review of Economic Impact Analysis for Tourism, Monetary Authority of Macao, p. 67- 81.

Popescu, R.-I., Zamfir, A., 2011. Strategic Role of Ecotourism for Romania's Regional Development, Think Globally, Act Locally, Change Individually in the 21st Century, p. 250-258. Romania, World Bank Report, 2012.

Rupert, M., Rattrout, A., Hassas, S., 2008. The Web from a Complex Adaptive Systems Perspective, Journal of Computer and System Sciences, p. 133-145.

Schuber, S. F., Brida, J. G., Wiston, A. R., 2011. The Impacts of International Tourism Demand on Economic Growth of Small Economies Dependent on Tourism, Tourism Management, p. 377-385.

Stevenson, N. A., 1999. Complexity Theory and Tourism Policy Research International, Journal of Tourism Policy, p. 206 - 220.

Stynes, D. (1999). Economic Impacts of Tourism, Editor. Recreation \& Tourism Resources, Michigan State University, p. 1-19.

Tourism, National Institute of Statistics, 2012. Vasconcelos, F. C., Rafael, R., 2011. Complexity in Business Environments, Journal of Business Research, p.236-241.

Weidenfeld, A., 2013. Tourism and Cross Border Regional Innovation Systems, Annals of Tourism Research, p. 191-213.World Trade Organization Report, 2012. 